\title{
Coral Bleaching Susceptibility Is Decreased following Short-Term (1-3 Year) Prior Temperature Exposure and Evolutionary History
}

\author{
Joshua A. Haslun, ${ }^{1}$ Kevin B. Strychar, ${ }^{1}$ Gregory Buck, ${ }^{1}$ and Paul W. Sammarco ${ }^{2}$ \\ ${ }^{1}$ Department of Life Sciences, Texas A\&M University-Corpus Christi, 6300 Ocean Drive-Unit 5869, Corpus Christi, TX 78412, USA \\ ${ }^{2}$ Louisiana Universities Marine Consortium (LUMCON), 8124 Highway 56, Chauvin, LA 70344, USA
}

Correspondence should be addressed to Kevin B. Strychar, kevin.strychar@tamucc.edu

Received 16 March 2011; Accepted 4 June 2011

Academic Editor: Baruch Rinkevich

Copyright (C) 2011 Joshua A. Haslun et al. This is an open access article distributed under the Creative Commons Attribution License, which permits unrestricted use, distribution, and reproduction in any medium, provided the original work is properly cited.

\begin{abstract}
Coral exposed to short periods of temperature stress $\left(\geq 1.0^{\circ} \mathrm{C}\right.$ above mean monthly maximum $)$ and/or increased frequencies of high temperatures may bolster resilience to global warming associated with climate change. We compared Montastraea cavernosa (Linnaeus, 1767; Cnidaria, Scleractinia, Faviidae) from the Florida Keys National Marine Sanctuary (FKNMS) and the Flower Garden Banks National Marine Sanctuary (FGBNMS). Thermal stress has been reported frequently within the FKNMS; however, corals in the FGBNMS experience nominal exposures to similar stressors. Corals were exposed to three temperatures $\left(27^{\circ} \mathrm{C}, 31^{\circ} \mathrm{C}\right.$, and $35^{\circ} \mathrm{C}$ ) for $72 \mathrm{~h}$. Colonies from the FKNMS lost significantly fewer viable and necrotic zooxanthellae under conditions of acute stress $\left(35^{\circ} \mathrm{C}\right)$ than the FGBNMS colonies. This indicates that the FKNMS corals are less temperature-sensitive than those in the FGBNMS. The observed differences point to greater prior temperature exposure and adaptation in the former versus the latter site when correlated to previous years of thermal exposure.
\end{abstract}

\section{Introduction}

The earliest reefs are believed to have existed more than 3.4 billion years ago, dating back to the Early Archean era [1]. Reefs at that time were likely dominated by cyanophyceans and other bacteria [2]. More "modern" reefs consisting of coral and algae evolved during the Oligocene and Miocene, $\sim 5$ million years ago [3]. Present day reefs, such as the IndoPacific Great Barrier Reef (GBR) have evolved over the last $500-600 \mathrm{~K}$ years [4]. During each of these major eras of reef development, major climate changes throughout the geological time are believed to have influenced the evolution of species and the subsequently, adaptation of surviving species to these changes [1]. Such changes are believed to include the evolution of symbiosis. To better understand how future reefs will adapt to present-day climate changes, numerous studies have been done (reviewed in [5-10]). The causes of present-day crises on coral reefs is believed to be most likely a synergism between natural climate-related stress exacerbated by human-imposed stress. In 1998, heat stress is believed to have caused $48 \%$ of western Indian Ocean reefs and $16 \%$ of all reef areas globally to bleach $[11,12]$. In 2002, extensive bleaching occurred on $60-95 \%$ of the world's barrier reefs, causing the loss of $50-90 \%$ of the corals there [12]. On the Great Barrier Reef, Australia, 50-60\% of the reefs bleached, affecting 75,000 to $210,000 \mathrm{~km}^{2}[13,14]$.

Disease has also been a major cause of loss of coral cover in the Caribbean Sea. Changes in climate in combination with an increase in the incidence of coral disease [15-20] have resulted in a major decrease in the live coral cover. Between 1984 and 1991, the live coral cover decreased by as much as $49 \%$ at certain sites in the Florida Keys [21]. In fact, damage inflicted on Caribbean corals by heat stress (i.e., increased seawater temperatures; SWTs) and disease is causing a shift from a coral-dominated community [22] to one dominated by algae [20, 23-25]. There have been numerous studies in the Caribbean on the causes and mechanisms of corals bleaching $[6,26]$, including the probability that some corals can "cope" with heat stress better than their symbionts [10], which may be related to their evolutionary age and/or 
their prior experiences/exposures to specific stressors. In general, corals in the Florida Keys are relatively younger (5$7 \mathrm{~K}$ years old; [27]) than those in the Gulf of Mexico (i.e., $10 \mathrm{~K}$ years old; [28]) but have been exposed to a greater number of heat waves, pollution, and diseases. Here, we ask whether corals in the Florida Keys are better adapted for long-term survival of increasing seawater temperatures than those in the Gulf of Mexico because of prior exposure to such stresses (e.g., bleaching) through time in terms of frequency and level.

The coral reefs of the FGBNMS occur at $\sim 180$ kilometers offshore from Galveston, Tex, USA, in clear, pristine waters where visibility is $\geq 30 \mathrm{~m}$ ([29]; J. A. Haslun, K. B. Strychar, P. W. Sammarco, pers. obs.). Although past monitoring efforts indicate a healthy reef environment with little to no bleaching, a high degree of bleaching was recorded in the fall of 2005 when sustained temperatures above mean monthly maximums (MMM) were recorded at the FGBNMS. Bleaching in the fall of 2005 was observed in $42-46 \%$ of all coral on both the East and West banks; this percentage of corals affected by bleaching decreased to $4-10 \%$ by January (2006), with most recovering over that three to four month seasonal time period [30]. This paper is believed to be the first of any type of massive bleaching experienced by these reefs [31].

Bleaching is defined as the whitening in appearance of a coral when the endosymbiotic zooxanthellae die or are lost, causing the underlying white calcium carbonate skeleton to become visible through the transparent coral tissue [32-34], particularly after exposure to acute or chronic increases in SWTs. Small changes to a reef ecosystem, particularly shifts in SWTs by $0.5-1.0^{\circ} \mathrm{C}$ above the MMM, can result in bleaching $[35,36]$. Corals have also exhibited resilience following a bleaching event, recovering weeks to months later following thermal stress [6, 37]. Jones et al. [38] discuss two mechanisms by which this can occur: (1) the colony is either able to recover fully from thermal stress, or suffer only partial mortality due to the independence of individual polyps increasing their feeding rate within a colony; or (2) following a bleaching event, the coral is unable to respond to the loss of the symbiont resulting in colony mortality. Both of these trends have been well documented. For example, on the Great Barrier Reef (GBR) of Australia, Acropora spp. corals were subjected to uncharacteristically high SWTs, causing up to $88 \%$ mortality [39]. Oxenford et al. [40], however, reported bleaching equivalent to $\geq 70 \%$ of coral species, located near Barbados in the southeastern Caribbean in 2005. They categorized this as the most severe bleaching event recorded in Barbados; however, mortality was minimal as many coral recovered. Such corals are hypothesized to "reassociate" with better-adapted zooxanthellae. This concept has been termed the "Adaptive Bleaching Hypothesis" (ABH) [41-43], and its effectiveness is dependent upon both the intensity and duration of the stress [6].

The symptoms of bleaching have also been traditionally broken down into 2 cell phenomena: (1) apoptosis and (2) necrosis [44-46], both collectively part of cell death processes. Apoptosis is a preprogrammed or encoded event that is initiated following a stress stimulus and subsequent signaling cascade within the cell, including a reduction in cell size over time concurrent with the externalization of the membrane-bound molecule phosphatidylserine resulting in its dismantling without inflammation or the stress signaling of other cells [47-50]. Other characteristics of apoptosis include symmetrical DNA cleavage patterns (multiple integers of $\sim 180-200 \mathrm{bp}$ ) for apoptosis, versus random patterns associated with necrosis. Necrosis, on the other hand, is indicative of extreme trauma, with characteristic increases in cell size followed by cell rupture and inflammation at the site of insult, resulting in cell death $[47,51]$. Strychar et al. [52] documented these processes to occur not only in the zooxanthellae in situ but also in the tissue of host corals. Using flow cytometry, Strychar et al. [52] determined that the concentration of live zooxanthellar cells in water samples obtained from corals subjected to hyperthermal stress $\left(34^{\circ} \mathrm{C}\right)$ decreased with time while the concentration of apoptotic and necrotic cells increased. Lower experimental temperatures did not induce significant apoptosis or necrosis. This was an indication that such corals were already adapted (or exapted) to higher seawater temperatures [10].

A third mode of cell death, autophagy [53, 54], has recently been observed to participate in cnidarian bleaching. Autophagy is a stress-dependent pathway in which identified targets including organelles, protein, and foreign intracellular pathogens are removed from the cell through the production of an autophagosome and digestion from hydrolytic enzymes therein ([55], reviewed by [56]). Dunn et al. [53] determined that autophagy occurs to some extent along with apoptosis during bleaching. Further, Downs et al. [54] reported on the autophagy of symbiotic dinoflagellates referring to this particular process as symbiophagy during the cnidarian bleaching response. Although these three modes of cell death appear to play a role in the bleaching response, their mechanisms still remain unclear.

The objectives of this study are to compare and contrast the physiology of zooxanthellae expelled from Montastraea cavernosa collected from two geographically separated sites-the FGBNMS and FKNMS. We will attempt to determine whether corals from the FGBNMS are more susceptible to thermal stress and exhibit a higher frequency of cell death responses (necrosis and apoptosis) than corals from the FKNMS, which are frequently reported to experience high seawater temperatures and thermal stress.

\section{Methods}

2.1. Target Species. We chose to use the host species Montastraea cavernosa as our experimental coral because it is well represented in both the FGBNMS (Texas) and FKNMS (Florida) and may be a good bioindicator species for thermal stress. The corals M. cavernosa (Linnaeus, 1767) and Millepora alcicornis (Linnaeus, 1758) are reported to be the most sensitive to thermal stress at the FGBNMS [30, 31]. Most other massive and encrusting species present, such as poritids and faviids, are much less sensitive [57-59]. Montastraea cavernosa is also abundant, easily recognizable, and its taxonomy has been well described. 
2.2. Collection Sites. We sampled from one site within the Gulf of Mexico (GOM) - the West Flower Garden Bank (27 $\left.52^{\prime} 35.1^{\prime \prime} \mathrm{N}, 93^{\circ} 48^{\prime} 54.1^{\prime \prime} \mathrm{W}\right)$ National Marine Sanctuary (FGBNMS) located in the northwestern GOM, $\sim 190 \mathrm{~km} \mathrm{SE}$ of Galveston, Tex, USA [29]. The FGBNMS is comprised of two reefs, the East Bank ( $27^{\circ} 54^{\prime} 35.9^{\prime \prime} \mathrm{N}, 93^{\circ} 35^{\prime} 49.7^{\prime \prime} \mathrm{W}$ ) and the West Bank, which are $19 \mathrm{~km}$ apart and $65.8 \mathrm{~km}^{2}$ and $77.2 \mathrm{~km}^{2}$ in area, respectively [60]. Seasonal water temperatures range from $\sim 20^{\circ} \mathrm{C}$ in mid-February to $30^{\circ} \mathrm{C}$ in August [30]. The second site was the Florida Keys National Marine Sanctuary (FKNMS) which is $\sim 4,506 \mathrm{~km}^{2}$ and is located at the southern tip of Florida where the GOM loop current exits into the Caribbean [27].

2.3. Coral Collection and Maintenance. Twenty-four fragments of Montastraea cavernosa were collected from the West Bank of the FGBNMS with the assistance of SCUBA divers. Coral fragments $\sim 2.5 \mathrm{~cm}^{2}$ in size were excised from parent colonies at $23-25 \mathrm{~m}$ depth with a cold chisel and mallet (one fragment per colony) and placed in individual $50 \mathrm{~mL}$ plastic cylindrical bottles prefilled with water derived from the site of collection. Bottles were placed in netted collection bags and transported to the surface.

Aboard the vessel, individual coral fragments were removed from the bottles and submerged in a stress-relieving solution (Kent Marine Tech D parasite and bacterial dip) for 5 mins to prevent bacterial infection caused by excision from the parent colony. Samples were then placed and stored in a modified cooler fed with site-derived water pumped continuously from a depth of $\sim 1 \mathrm{~m}$ using a submersible pump and a flow-through system to maintain a suitable environment for the coral during transport to Texas A \& M University-Corpus Christi (TAMUCC). A portable aeration system provided oxygen during transport. At TAMUCC, corals were transferred to a $1,703 \mathrm{~L}$ quarantine tank consisting of a protein skimmer, refugium, UV light, water heater/chiller, and an automatic reverse osmosis deionized (RO DI) water-topping system for salinity maintenance. Fragments were acclimated to tank conditions for a minimum of two weeks prior to treatments and allowed to recover following collection. Coral color was monitored over this period using the Coral Color Reference Card technique developed by Siebeck et al. [61]. Specimens of M. cavernosa were used if they expressed the red color morph and were comparable to condition C6 of hue 8 on the reference card, indicating an abundance of symbionts equivalent to $\sim 3.0 \times 10^{6}$ zooxanthellae $\mathrm{cm}^{2}$.

Coral representatives of the FKNMS were obtained with assistance from Mote Marine Laboratory Tropical Research Station, Key West, Florida. Twenty-four coral fragments $\sim 2.5 \mathrm{~cm}^{2}$ were collected in and around the Naval Air Station (NAS) ship channel from a depth of 11-12 m. The fragments were shipped to TAMUCC and placed in a quarantine tank similar to the FGBNMS fragments where they were monitored over the next two weeks using the Coral Color Reference Card [61].

Although the collection depths of each coral sample population were different, evidence from Lesser et al. [62] indicates that $M$. cavernosa populations lying between 11 and
$30 \mathrm{~m}$ are not significantly different with respect to zooxanthellae population (cells $\mathrm{cm}^{-2}$ ), quantum yields, and chlorophyll concentration (total $\mu \mathrm{g} \mathrm{chl} \mathrm{cm}{ }^{-3}$, total pg chl cm${ }^{-3}$, and chl $a: c_{2}$ ratio) within the depth range of this study. Further, the cladal diversity of zooxanthellae within large geographic areas with respect to $M$. cavernosa has been shown to be consistently clade $\mathrm{C}$ although subtypes are present [63-68]. The areas of these studies span the Gulf of Mexico from the Bahamas to the Yucatan peninsula and to Bermuda. We also chose to only collect the adult red color morph of $M$. cavernosa in order to minimize the influence in host-derived pigments between fragments if present.

2.4. Experimental Design. We followed a Model I, repeated measures, three-way orthogonal experimental design in order to determine the thermal stress thresholds of Montastraea cavernosa from the FKNMS and FGBNMS. The three primary factors were water temperature, geographic site, and duration of exposure to water temperature. Each experimental trial consisted of twelve individual coral fragments collected as previously discussed. Four fragments were randomly assigned to each of three thermal stress temperatures $\left(28,31\right.$, and $\left.35^{\circ} \mathrm{C}\right)$ for a total of $n=4$ replicates. Fiftymilliliter water samples were collected from each replicate in $6 \mathrm{~h}$ intervals over $72 \mathrm{~h}$ in order to quantify and determine the physiological condition of expelled zooxanthellae. To increase the total number of replicates sampled, each trial was repeated twice $\left(n_{i}=8\right)$.

2.5. Flow-Through Seawater System. Thermal stress experiments were carried out in a "Flow-Through Seawater System" (FTSWS). The seawater used for this study was obtained from the Upper Laguna Madre, Corpus Christi, Tex, USA and delivered by Texas Parks and Wildlife Department (TPWD) to our FTSWS wet lab located at TAMUCC (Figure 1). All seawater was filtered through a $20 \mu \mathrm{m}$ filter by TPWD prior to delivery. We then pumped the seawater through a $5 \mu \mathrm{m}$ filter into five $189 \mathrm{~L}$ fiberglass cylindrical storage tanks (Figure 1). Practical salinity was maintained at 34 by the addition of deionized water when necessary. In this study, we are using practical salinity which is a dimensionless unit as recommended by the International Association for the Physical Sciences of the Oceans [59] and adopted by the International System of Units (SI) in 1985. A closed recirculation system consisting of a sand filter coupled with a UV filter (Figure 1) served as a tertiary filtration system for the experimental water, which was run for $\geq 2$ days prior to any experimentation. Oxygen was delivered continuously via a Thomas 5030A electrical air pump, common to each of the five diffuser lines feeding the five cylindrical water tanks (Figure 1); oxygen levels were maintained at $\sim 5-6 \mathrm{mg} \mathrm{L}^{-1}$.

Seawater was gravity-fed from the five storage tanks into two manifolds. Each manifold fed six $19 \mathrm{~mm}$ hose barbs with Nalgene tubing. Each of these was attached to one of two 6-channel peristaltic pumps (PP; Figure 1). The PP controlled the rate of seawater entering each of the twelve $1 \mathrm{~L}$ incubation chambers (IC), delivering a constant flow rate of $12.5 \mathrm{~mL} \mathrm{~min}^{-1} \pm 0.3 \mathrm{~mL}$ to each IC (Figure 2). To help 


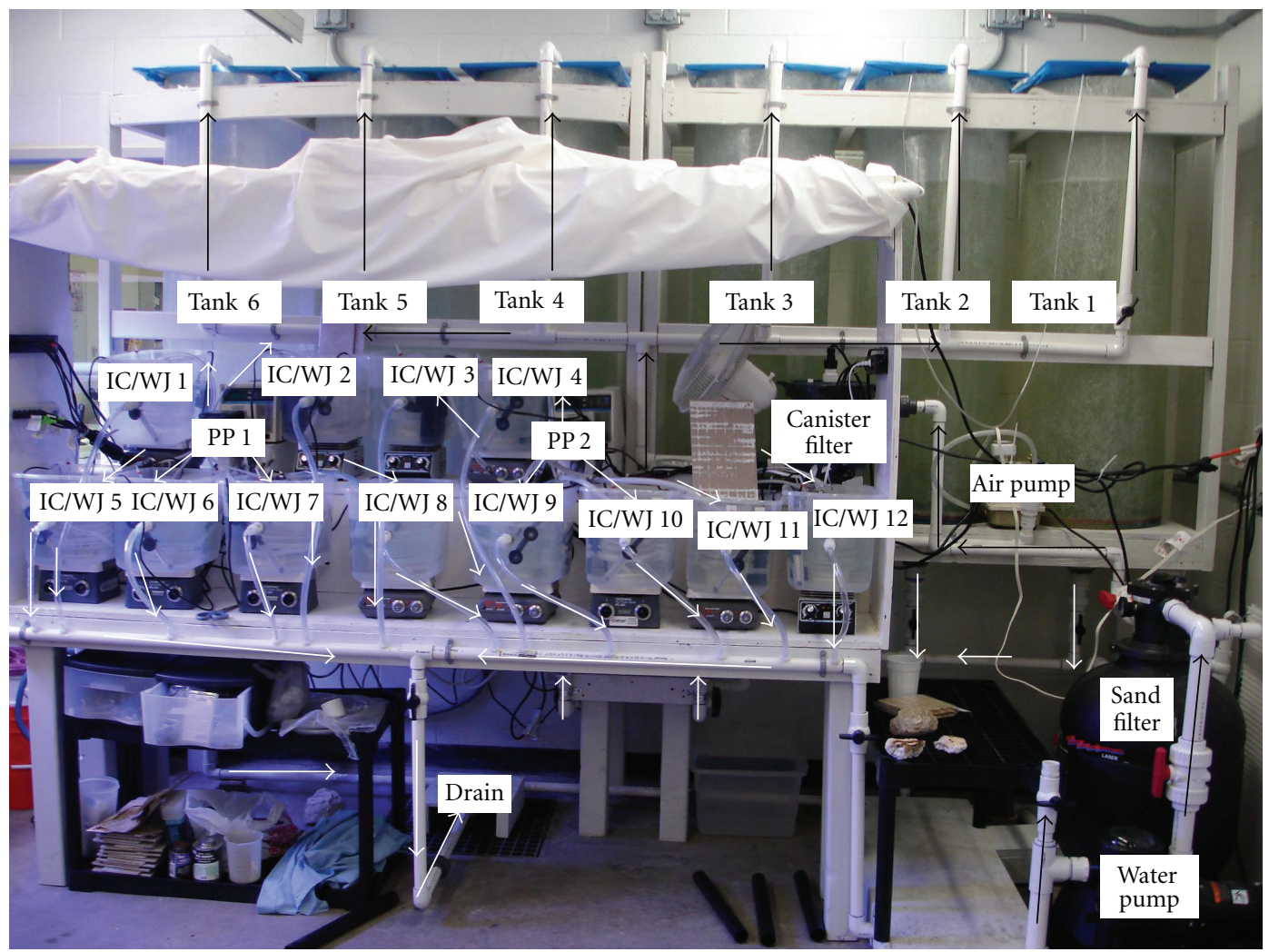

FIGURE 1: Flow-through seawater system consisting of sand and UV light filtration. Water was pumped into five of the six storage tanks through the filter system by a $1.5 \mathrm{hp}$ centrifugal Jacuzzi pump (pump and filter system used only prior to experimentation to prevent pump cavitation). Incoming water enters the pump, passes through the sand filter and a $5 \mu \mathrm{m}$ Canister filter coupled with UV-light sanitization, and is then passed to the storage tanks. During experimental trials, water is pumped to the twelve incubation chambers (IC), exiting via a drain.

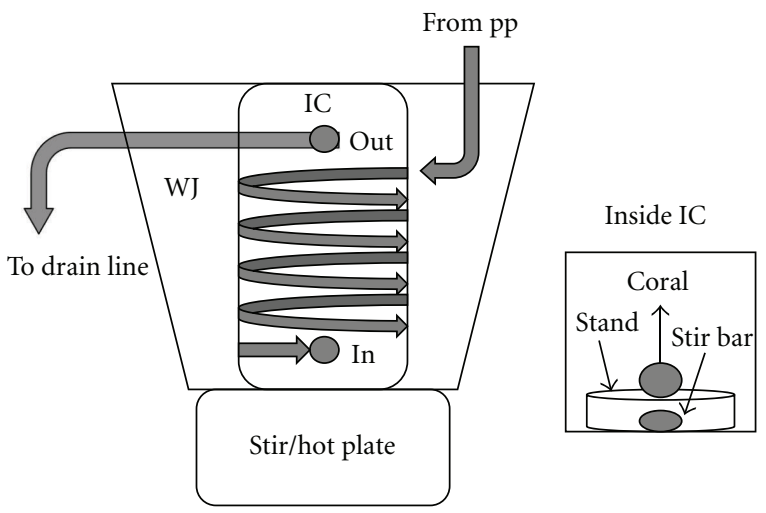

FIGURE 2: Schematic representation of a single incubation chamber (IC) and water jacket (WJ). Upper arrows represent the direction of water flow. Arrows encircling the IC represent tubing bathed within the WJ. Inset: magnified view of contents within an IC.

maintain IC seawater temperatures, each IC was housed in a $17.9 \mathrm{~L}$ water jacket $(\mathrm{WJ})$, and each of these contained a $75 \mathrm{~W}$ Jager aquarium heater. In addition, $3 \mathrm{~m}$ of Nalgene tubing wrapped around the peripheral of the IC also helped maintain constant temperatures (Figure 2). From each PP, water was pumped through this tubing, subsequently entering each IC at one of three temperatures: $27^{\circ} \mathrm{C}$ (control), $31^{\circ} \mathrm{C}$, or $35^{\circ} \mathrm{C}$. Each IC contained a coral fragment, which rested on a stand below which a single stir bar was placed (Figure 2). Each WJ was placed on top of a stir plate turned on at $\sim 300 \mathrm{rpm}$ in order to maintain a thermally well-mixed water column. Excurrent tubing from each IC was attached to a single drain line common to all chambers (Figure 1).

Environmental parameters were monitored every $12 \mathrm{~h}$ including flow rate $\left(\mathrm{mL} \min ^{-1}\right)$, practical salinity, temperature $\left({ }^{\circ} \mathrm{C}\right)$, and photosynthetically active radiation (PAR in 
$\mu \mathrm{E} \mathrm{m}^{2} \mathrm{~s}^{-1}$ ); photographs were also taken of coral fragments throughout each trial.

2.6. Sampling of Expelled Zooxanthellae. Sampling methods were adapted from Strychar et al. [44, 46]. Seawater samples $(50 \mathrm{~mL})$ were obtained every $6 \mathrm{~h}$ for $72 \mathrm{~h}$ using plastic syringes, one for each individual IC. Seawater samples were deposited into separate $50 \mathrm{~mL}$ Falcon conical centrifuge tubes and centrifuged at a relative centrifugal field of $700 \times \mathrm{g}$ for $5 \mathrm{~min}$ in a Beckman Coulter Allegra 25R centrifuge. The supernatant was decanted leaving $5 \mathrm{~mL}$ remaining in the sample tube, and $2 \mathrm{~mL}$ of the suspended solution was equally separated into two $1.5 \mathrm{~mL}$ microcentrifuge tubes prior to centrifuging again at $700 \times \mathrm{g}$ for $5 \mathrm{~min}$ in an Eppendorf Centrifuge 5415D. One group of aliquots ( 12 tubes) was used to determine the number of live, dead, and mitotic cells using light microcopy and a hemocytometer while a second group of twelve aliquots was used to assess cell viability using flow cytometry (FCM).

2.7. Light Microscopy and Hemocytometry. The supernatant from each tube of the first set of twelve aliquots was discarded, leaving $200 \mu \mathrm{L}$ in each tube without disturbing the pelleted cells. The cells were stained with trypan blue $(0.2 \%, \mathrm{BDH}$ Chemicals) in phosphate-buffered saline (PBS; $1: 1)$ and gently vortexed for $5 \mathrm{sec}$ before incubating at room temperature for $5 \mathrm{~min}$. Two $10 \mu \mathrm{L}$ subsamples were then loaded into each side of a Neubauer-improved hemocytometer (Marienfeld), which were then visualized using a XDY-1 inverted microscope at $100 \times$ magnification. Light microscopy helped to determine zooxanthellar density and cell viability. Cells were considered viable if their membranes were intact and the DNA-binding Trypan blue was excluded from the cell. Cells were considered mitotic if "doublets" were observed. Necrotic cells appeared blue and exhibited either the basic shape of live cells or the expulsion of their contents. Concentrations of cell types were determined using the following equation (traditional hemocytometer calculations, Hausser Scientific Co.):

$$
\begin{aligned}
\frac{\text { Zooxanthellae }}{\mathrm{mL}}= & \frac{\left((\text { total } / 2 \text { replicates }) / 5.0 \mathrm{~mm}^{2}\right) \times 1000}{50 \mathrm{~mL}} \\
& \times \frac{15 \text { samples }}{\mathrm{IC}} .
\end{aligned}
$$

2.8. Flow Cytometry (FCM). The second set of aliquots consisting of twelve microcentrifuge tubes used for FCM were prepared using $100 \mu \mathrm{L}$ of $1 \times$ Annexin-binding buffer (ABB) added to each microcentrifuge tube following the recommendations of the manufacturer. This step was followed by the addition of $1 \mu \mathrm{L}$ propidium iodide (PI; $100 \mu \mathrm{g} \mathrm{mL}^{-1}$; Invitrogen) and $3 \mu \mathrm{L}$ of Annexin V-fluor $488 \mathrm{~nm}$ conjugate (Invitrogen). The 12 microcentrifuge tubes were then incubated at room temperature in the dark for $30 \mathrm{~min}$. Following incubation, an additional $400 \mu \mathrm{L}$ of $\mathrm{ABB}$ was added to each microcentrifuge tube and the contents gently vortexed for $1 \mathrm{~min}$. After vortexing, the solution was transferred by pipette to a $5 \mathrm{~mL}$ BD Falcon round-bottom tube (one tube per microcentrifuge tube) for analysis via FCM.

A FACSVantage SE flow cytometer (Becton Dickinson) equipped with a $488 \mathrm{~nm}$ laser was used to identify and quantify viable, necrotic, apoptotic, and postapoptotic zooxanthellar cells in each sample. A fluorescein isothiocyanate (FITC) 530/30 band-pass FL-1 filter detected green fluorescence whilst a LSRI Red 630/22 band-pass FL-3 filter was used to detect red fluorescence, in order to differentiate between each of the four cell death categories. On a scatter-plot of FL-1 versus FL-3 cells displaying increased phosphatidylserine exposure and thus apoptosis, such cells would be stained with the fluorescent green Annexin Vfluor and thus, display an increase in the FL-1 parameter. Cells displaying necrotic characteristics would be stained red by the membrane-impermeable dye PI and green as all phosphatidylserine will be stained by Annexin V-flour. This results in live cells predictably in the lower left quadrant (no stains), apoptotic cells in the lower right quadrant (green fluorescence only), and dead cells in the upper right quadrant (red and green fluorescence). All data were visualized and plotted using the manufacturers CwllQuest-Pro software.

2.9. Statistical Analyses. Refer to section 2.4 for statistical model parameters. Coral fragments were chosen and assigned to treatments randomly. Data were analyzed using SPSS V17 and the general linear model (GLM) repeatedmeasures, analysis of variance (ANOVA). Hemocytometry and FC data were not compared directly due to differences in data format (percent versus count).

All data were tested for significant variation due to sphericity using the Greenhouse-Guyser correction (Sphericity < 0.75 ) or the Huynh-Feldt correction (Sphericity $>0.75$; Field, 2009). Since the data lacked sphericity, Tukey's and GamesHollow post hoc tests were applied after analysis via GLM repeated-measure ANOVAs to examine specific significant differences between various means. Data displaying significant variations over time (h) were Bonferroni corrected. Higher-order interactions will only be mentioned and discussed if significant.

\section{Results}

The environmental variables that were monitored, including temperature and PAR, were stable over the $72 \mathrm{~h}$ time period.

3.1. Hemocytometry: Flower Garden Banks National Marine Sanctuary (FGBNMS). The number of viable zooxanthellae expelled from the coral per unit time was initially very high and then decreased through time. When stressed at $35^{\circ} \mathrm{C}$ (maximum temperature treatment), a maximum of 2,750 cells $\mathrm{mL}^{-1}$ were expelled at $36 \mathrm{~h}$; this dropped to 1,250 cells $\mathrm{mL}^{-1}$ at $66 \mathrm{~h}$. At the lower temperatures, loss of cells from the holobionts was $<1,000$ cells $\mathrm{mL}^{-1}$ during any given time period (Figure 3(a1)). Necrotic zooxanthellar cells expelled from corals exposed to $35^{\circ} \mathrm{C}$ followed an increasing then decreasing trend, starting at 400 cells $\mathrm{mL}^{-1}$ at $6 \mathrm{~h}$, increasing to 1,050 cells $\mathrm{mL}^{-1}$ at $42 \mathrm{~h}$, and then falling to 

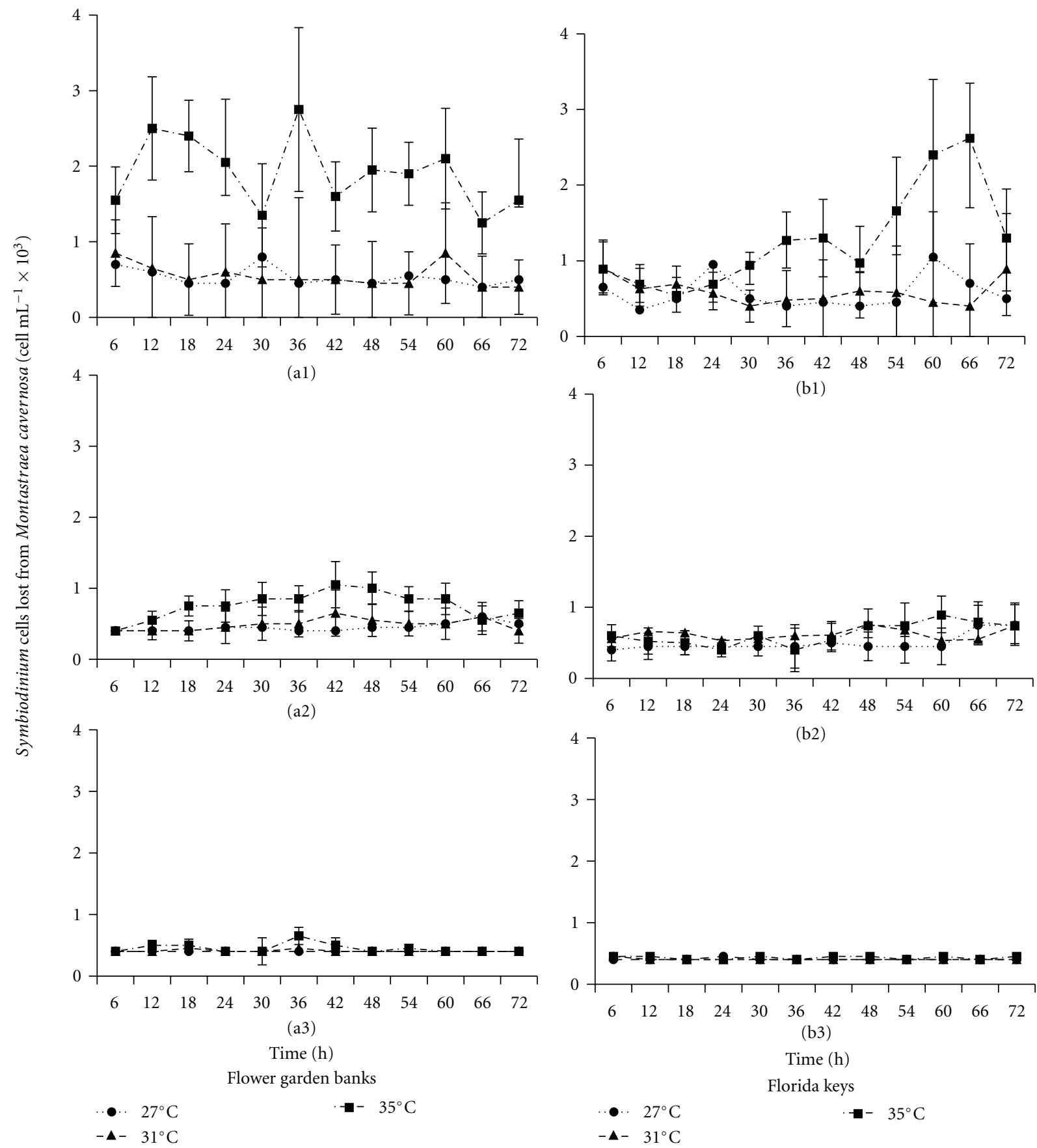

Florida keys

$\therefore \bullet 27^{\circ} \mathrm{C}$

$\rightarrow-35^{\circ} \mathrm{C}$

Figure 3: Hemocytometry data showing the mean temporal loss of viable (a1, b1), necrotic (a2, b2), and mitotic (a3, b3) zooxanthellae cells $\left(\times 10^{3} \mathrm{~mL}^{-1}\right)$ expelled from Montastraea cavernosa collected from the Flower Garden Banks National Marine Sanctuary (a1-3)) and the Florida Keys National Marine Sanctuary (b1-3)) sampled every $6 \mathrm{~h}$ over a $72 \mathrm{~h}$ time period at $27^{\circ} \mathrm{C}(\boldsymbol{\bullet}), 31^{\circ} \mathrm{C}(\boldsymbol{\Delta})$, and $35^{\circ} \mathrm{C}(\boldsymbol{\square})$. Error bars represent $95 \%$ confidence intervals $\left(n_{i}=8\right)$; some error bars are too small to be seen.

550 cells $\mathrm{mL}^{-1}$ at $66 \mathrm{~h}$ (Figure 3(a2)). There were no significant differences in the concentrations of mitotic symbiont cells expelled between any of the temperature treatments (Figure 3(a3)).

In terms of cumulative loss, both viable (Figure 4(a1)) and necrotic (Figure 4(a2)) expelled zooxanthellae were significantly greater in the $35^{\circ} \mathrm{C}$ treatment than in the $27^{\circ} \mathrm{C}$ control and $31^{\circ} \mathrm{C}$ treatments (ANOVA; $P<0.005$ ). The concentration of mitotic cells lost, however, did not vary significantly (Figure 4(a3)). Concentrations of live zooxanthellae were consistent across temperatures and time, with the exception of $t=30,36$, and $66 \mathrm{~h}$ (Figure 4(a1): $P<$ 0.05, Games-Hollow post hoc test). Significant differences in necrotic zooxanthellae concentrations were observed 


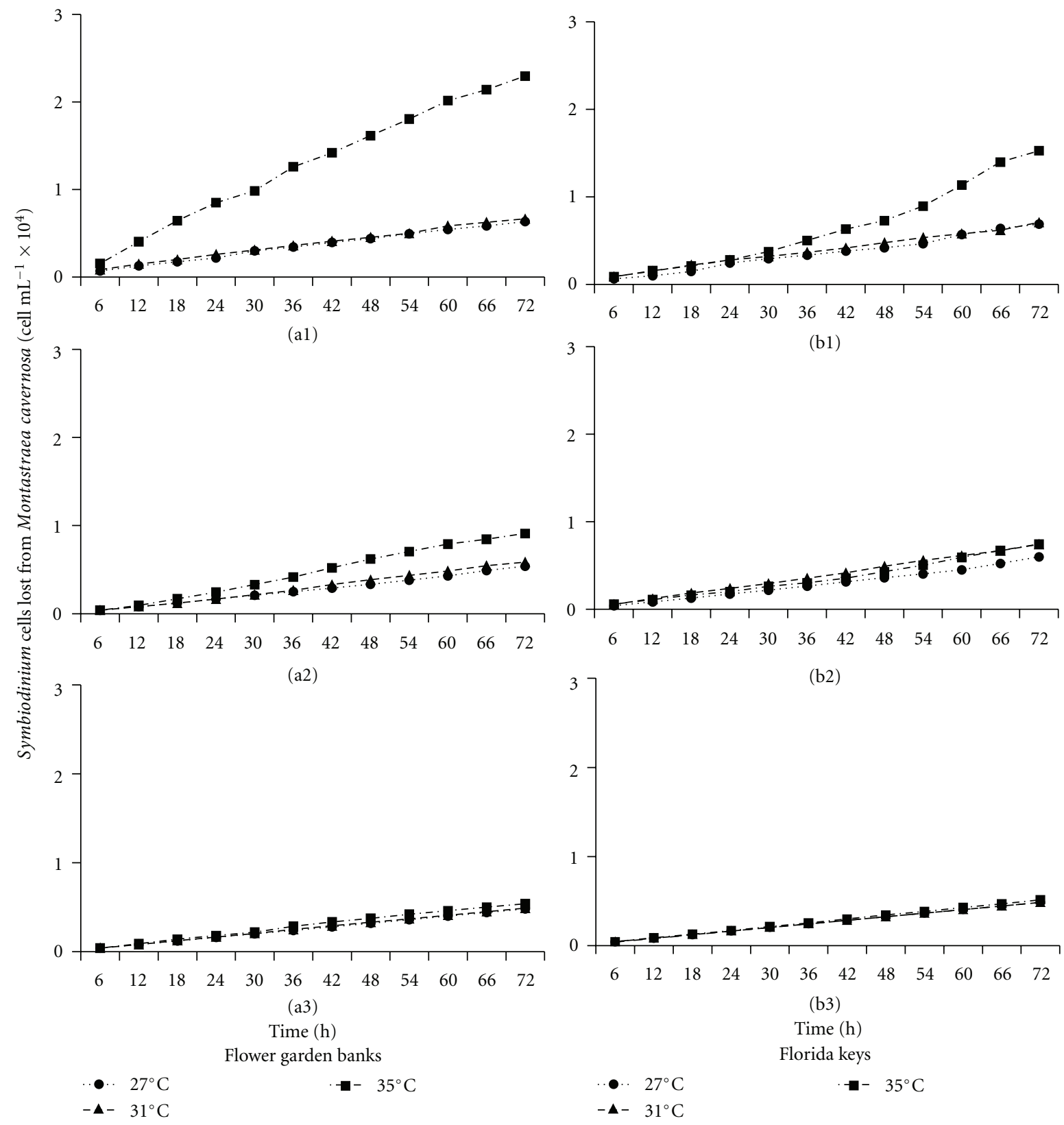

Figure 4: Hemocytometry data showing the mean cumulative loss of viable (a1, b1), necrotic (a2, b2), and mitotic (a3, b3) zooxanthellae cells $\left(\times 10^{3} \mathrm{~mL}^{-1}\right)$ expelled from Montastraea cavernosa collected from the Flower Garden Banks National Marine Sanctuary (a1-3)) and the Florida Keys National Marine Sanctuary (b1-3)) sampled every 6 h over a $72 \mathrm{~h}$ time period at $27^{\circ} \mathrm{C}(\boldsymbol{\bullet}), 31^{\circ} \mathrm{C}(\boldsymbol{\Delta})$, and $35^{\circ} \mathrm{C}(\boldsymbol{\square})$. Error bars represent $95 \%$ confidence intervals $\left(n_{i}=8\right)$; some error bars are too small to be seen. Note how cumulative graphs illustrate the effect of temperature on overall depletion of a coral's Symbiodinium complement over $72 \mathrm{~h}$.

between the control and maximum temperature treatment at $t=18,36,42,48$, and $54 \mathrm{~h}(P<0.05$; Figures $3(\mathrm{a} 2)$ and $4(\mathrm{a} 2))$. Total cumulative concentrations of viable, dead, and mitotic zooxanthellae at $27^{\circ} \mathrm{C}$ (control) and $31^{\circ} \mathrm{C}$ (Figure 4(a1-2)) did not vary significantly through time.

\subsection{Hemocytometry: Florida Keys National Marine Sanctuary} (FKNMS). Concentrations of expelled viable zooxanthellar cells varied significantly between all temperature treatments
(ANOVA, $P<0.01$; Figure 3(b1)). Corals incubated at $35^{\circ} \mathrm{C}$ experienced a greater loss of symbiont cells than at $27^{\circ} \mathrm{C}$ and $31^{\circ} \mathrm{C}$ (ANOVA; $P<0.05$; Figure 3(b1)). Concentrations of viable zooxanthellae did not vary with temperature when exposed for $\leq 30 \mathrm{~h}$ ( $P>0.05$, GLM ANOVA). After $30 \mathrm{~h}$ at $35^{\circ} \mathrm{C}$, concentrations of viable cells lost from the coral at first decreased to $\sim 600$ cells $\mathrm{mL}^{-1}$ at $18 \mathrm{~h}$, increased to 2,750 cells $\mathrm{mL}^{-1}$ at $66 \mathrm{~h}$, and then decreased again to $\sim 1,300$ cells $\mathrm{mL}^{-1}$ at $72 \mathrm{~h}$ (Figure 3 (b1)). Concentrations of 

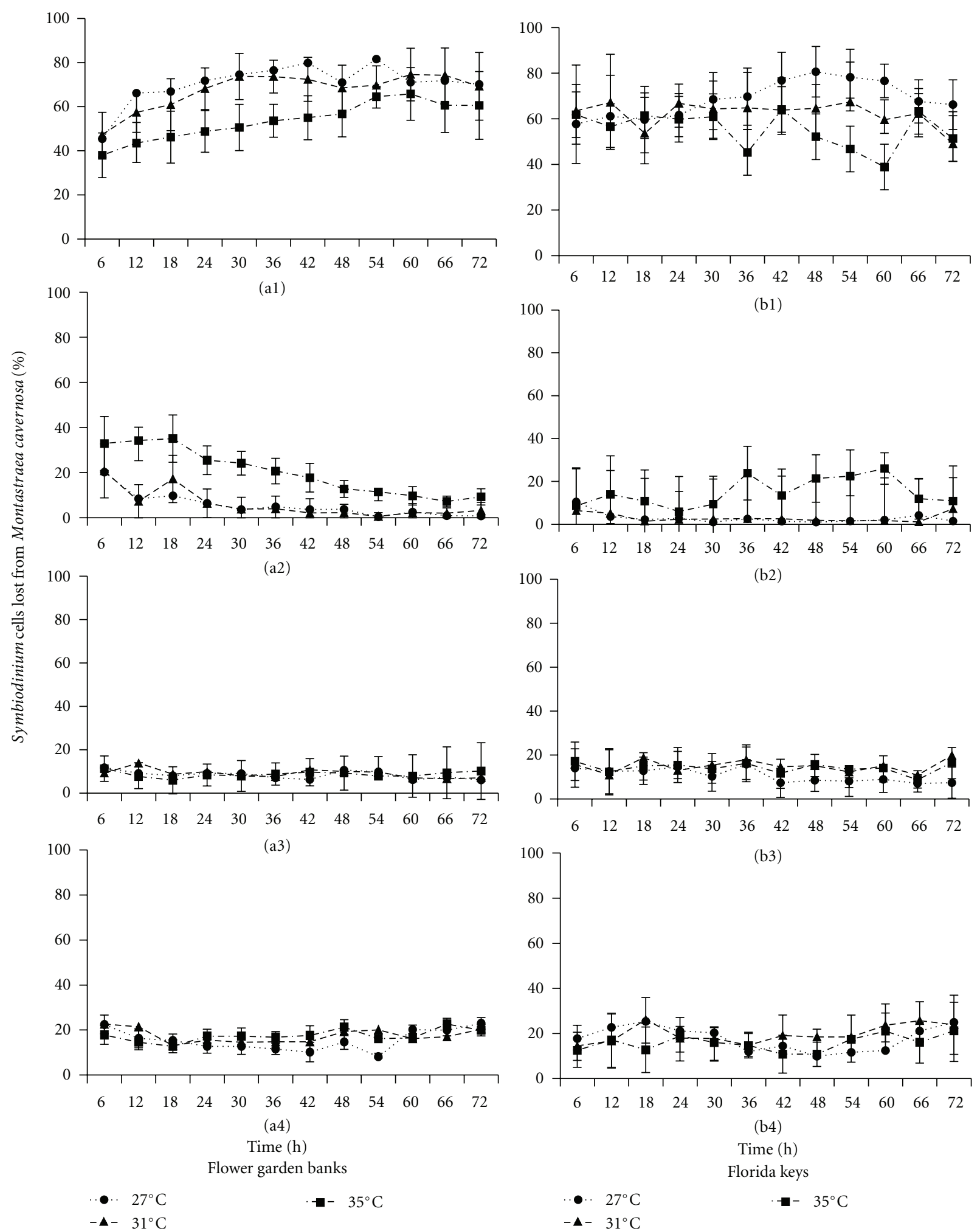

Figure 5: Flow cytometry data showing the mean temporal loss expressed as a percent (\%) of viable (a1, b1), necrotic (a2, b2), apoptotic (a3, b3), and postapoptotic (a4, b4) Symbiodinium cells expelled from Montastraea cavernosa collected from the Flower Garden Banks National Marine Sanctuary (a1-3)) and the Florida Keys National Marine Sanctuary (b1-3)) sampled every $6 \mathrm{~h}$ over a $72 \mathrm{~h} \mathrm{time} \mathrm{period} \mathrm{at} 27^{\circ} \mathrm{C}()_{)}$, $31^{\circ} \mathrm{C}(\boldsymbol{\Delta})$, and $35^{\circ} \mathrm{C}(\boldsymbol{\square})$. Error bars represent 95\% confidence intervals $\left(n_{i}=8\right)$; some error bars are too small to be seen. 


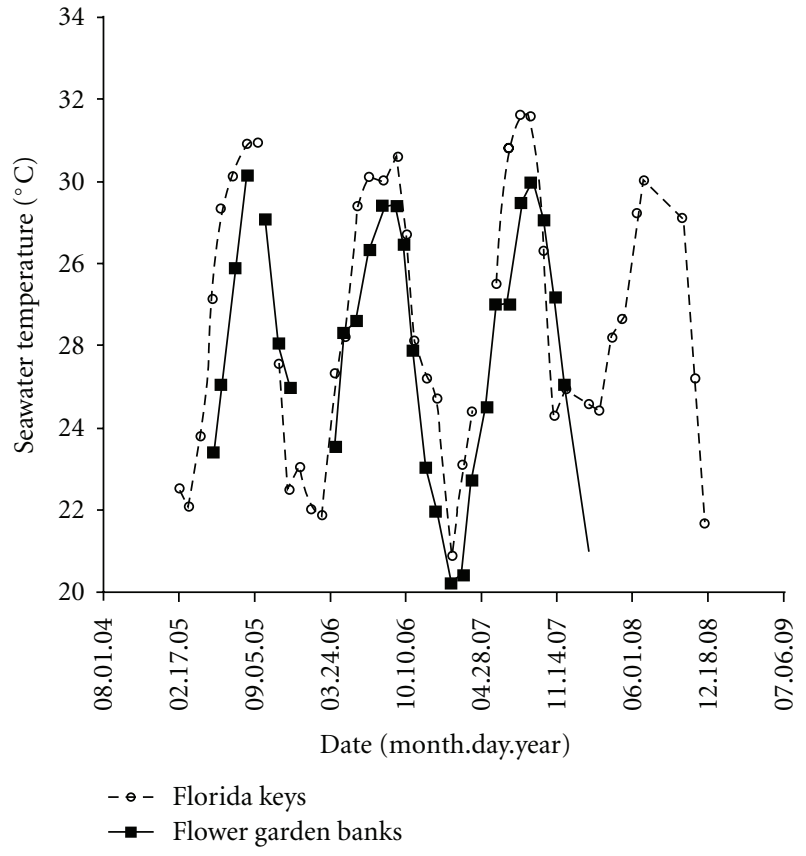

Figure 6: Temperature data spanning 2005-2008 from the West bank of the Flower Garden Banks National Marine Sanctuary (FGBNMS) and the Florida Keys National Marine Sanctuary (FKNMS). All measurements were taken with submerged YSI devices. The FGBNMS and FKNMS data set gaps were due to YSI maintenance and hurricane damage.

necrotic zooxanthellae released varied significantly between temperatures $(P<0.01)$ as well as time $(P<0.05$, ANOVA). Concentrations of mitotic cells lost did not vary significantly between temperatures or through time (Figure 3(b3)).

In terms of cumulative loss, only viable (Figure 4(b1)) expelled symbiont cells show a significant overall loss through time $(P<0.01$, ANOVA $)$. This pattern was consistent throughout the experiment $(P<0.05$, Games-Hollow post hoc test).

\subsection{Flow Cytometry: Flower Garden Banks National Marine} Sanctuary (FGBNMS). Flow cytometry revealed that zooxanthellar loss from FGB corals was significant through time (ANOVA, $P<0.01$ ) and varied significantly across experimental temperatures (ANOVA, $P<0.01$ ). The percent of viable zooxanthellae lost from the holobionts increased through time in all temperature treatments (Figure 5(a1)). Specifically, the mean percentage of viable expelled cells observed at $35^{\circ} \mathrm{C}$ was significantly lower than those at $27^{\circ} \mathrm{C}$ and $31^{\circ} \mathrm{C}(P<0.05$, Games-Hollow post hoc tests; Figure 5(a1)), with no significant differences between the latter two treatment effects $(P>0.05)$. The percentage of necrotic cells detected varied significantly between experimental temperatures $(P<0.01$, ANOVA $)$ as well as through time $(P<0.01)$. The mean percentage of necrotic cells expelled was the greatest at $35^{\circ} \mathrm{C}(P<0.01$, Games-Hollow post hoc test; Figure 5(a2)) with the greatest loss occurring within $24 \mathrm{~h}$. There was a general decline in necrotic cells over time $(p<0.01$, ANOVA; Figure 5(a2)), although no significant differences occurred between the control and $31^{\circ} \mathrm{C}$ treatments. There was no significant variation between temperatures or through time in apoptotic $(P>0.05$, Figure 5(a3) $)$ and post apoptotic $(P>0.05$, Figure 5(a4) cells.

3.4. Flow Cytometry: Key West National Marine Sanctuary (FKNMS). Percent viable zooxanthellae did not vary significantly between temperature treatments $(P>0.05$, ANOVA) or through time $(P>0.05$, Figure $5(\mathrm{~b} 1))$. Necrotic cells were lost at significantly different rates between temperatures $(P<$ 0.01 , ANOVA $)$ and times $(P<0.01$, Figure $5(\mathrm{~b} 2))$. A higher number of necrotic zooxanthellae were expelled from coral at $35^{\circ} \mathrm{C}$ than at $27^{\circ} \mathrm{C}$ or $31^{\circ} \mathrm{C}$, at 30,60 , and $66 \mathrm{~h}$ time intervals $(P<0.01)$. The percentage of apoptotic cells expelled did not vary significantly between temperatures; variation was detected, however, with time $(P<0.01$, Figure 5(b3)). A difference in the incidence of postapoptotic cells was also evident through time $(P<0.01$, Figure $5(\mathrm{~b} 4))$ but not between temperatures $(P>0.05)$. In general, the data followed a bimodal distribution through time for each temperature with two local maxima at $\sim 25 \%$, between $12 \mathrm{~h}$ and $18 \mathrm{~h}$ and another between $54 \mathrm{~h}$ and $72 \mathrm{~h}$ (Figure 5(b4)). Minima of $\sim 10,15$, and $11 \%$ were recorded between $36 \mathrm{~h}$ and $48 \mathrm{~h}$ time intervals at $27^{\circ} \mathrm{C}, 31^{\circ} \mathrm{C}$, and $35^{\circ} \mathrm{C}$, respectively, (Figure 5(b4)).

\section{Discussion}

The rate at which corals can adapt to increases in seawater temperature is of great concern worldwide. Mean global SWTs have increased by $\sim 0.5^{\circ} \mathrm{C}$ over the past century and are expected to continue to rise over the next several decades [69]. The deteriorating physiological state of expelled zooxanthellae is indicative of specific bleaching responses in a wide array of corals including both alcyonacean and scleractinian corals $[45,47]$. We speculate that the observed differences we found in Montastraea cavernosa between the Flower garden banks and the Florida keys populations may be attributed to adaptation/exaptation [10] or symbiont subtype shuffling. That is, the adaptation may be associated with intermittent $\sim 1$ month-long increases in SWTs over the last few decades in corals in the Florida keys compared to that of the Flower garden banks (Figure 6).

The fact that increased concentrations of viable zooxanthellae were expelled by $M$. cavernosa fragments from the FGBNMS as opposed to those from the FKNMS at higher experimental temperatures implies that (1) symbionts in corals inhabiting the FGBNMS may be more heat-sensitive than those inhabiting the FKNMS; (2) symbionts in corals from FKNMS may have become better adapted or acclimatized to increased seawater temperatures; (3) clade C symbionts with large temperature sensitivities are shuffled in $M$. cavernosa, or (4) the host itself has become better adapted to increased prevalence of heat stress in the FKNMS. Generally, bleaching occurs in corals exposed to temperatures $\geq 1{ }^{\circ} \mathrm{C}$ above the MMM in a given marine environment for a period 
of time on the order of days or weeks, defined as "Degree Heating Weeks" [35, 36]. Goreau and Hayes [35] coined the term "Degree Heating Weeks" by developing a modeling program referred to as "Hotspot" in combination with a satellite thermal detection system to detect bleaching events. A "hotspot" was deemed a region where the sea surface temperature (SST: defined as the upper $1 \mathrm{~m}$ of ocean) exceeded the annual $\mathrm{MMM}$ climatological value by $1.0^{\circ} \mathrm{C}$ for an observed number of weeks. The fact that zooxanthellate coral from the FKNMS tolerated $\sim 2$ months of increased temperature (E. Bartels, pers. com.), reaching or surpassing the bleaching criteria suggested by Goreau and Hayes [35] in 2005 and 2007, suggests that FKNMS zooxanthellae corals appear better adapted or acclimatized to heat stress. Conversely, very few subsurface temperatures $>30^{\circ} \mathrm{C}$ were recorded at the FGBNMS over a 3 -year period during the three warmest months (August-October; J. DeBose, pers. comm.). Temperature rarely exceeds MMM temperatures although isolated mass bleaching events have been observed [30].

The increased frequency of longer-term ( $\sim 2$ months) low-intensity heat stress may have allowed the Florida keys M. cavernosa zooxanthellar population to become better adapted to these environmental changes. Middlebrook et al. [70] discussed the role of specific patterns of temperature change over time in a given region and its influence on temperature adaptation in populations. They noted that the zooxanthellate Acropora sp. (harboring solely clade C3) pre-stressed at $31^{\circ} \mathrm{C}$ for $\leq 2$ weeks prior to a hyperthermic treatment could resist hyperthermic stress for at least 5 days $\left(34^{\circ} \mathrm{C}\right)$; coral not receiving such pretreatment exposure experienced a large decrease in symbiont density. This significant change was attributed to adaptations within the host alone and not the zooxanthellae population, specifically photoprotective mechanisms. Our data support the conclusions of Middlebrook et al. [70]. Seawater temperatures that frequently exceed the MMM slightly over a period of $\leq 2 \mathrm{y}$ in the Florida keys (E. Bartels, pers. com.) may have driven the coral host to become better adapted to heat stress. Although we cannot conclusively determine that clade $\mathrm{C}$ subtypes between sites had no effect on bleaching susceptibility and the expulsion of live, dead, or apoptotic zooxanthellae, authors from the published literature as previously discussed in section 2.3 suggest that the depths at which fragments were collected for this study, species utilized, and the condition of fragments at the point of collection $[68,71]$ allow for some interpretation with respect to the genetic diversity of clades within fragments between sites. Future studies should consider incorporating genetic studies to help determine if symbiont clade subtypes exist and whether those subtypes contribute to a host's ability to withstand episodes of bleaching. Hence, it is highly possible that symbiont clade subtype shuffling may affect bleaching susceptibility. Lesser et al. [62] noted that unique subtypes in $M$. cavernosa were described at depth (>30 m), and these, therefore, may play an important role in the holobiont survivorship. Further, many coral species have been found to be host-specific subtypes especially in high temperature stressed areas. Oliver and Palumbi [72] report that the corals Pocillopora damicornis and Acropora pulchra display distinct clade shuffling with respect to the frequency of high-temperature events. Clade C subtype C1 occurred in cooler pool inhabiting corals while Clade D was found in those coral inhabiting hotter pools. Although this dramatic difference in temperature was not the case with our particular sites, continued low degree temperature stress could impart a similar result. We, therefore, hypothesize that adaptation may be occurring in M. cavernosa at the FKNMS.

Low concentrations of apoptotic zooxanthellae cells were also detected in all temperature treatments from both experimental sites. The frequency of apoptosis in symbiont cells lost at all temperatures suggest that either the incubation at $31^{\circ} \mathrm{C}$ was not a significant stress, the length of time at each temperature treatment was too short, or the incubation at $35^{\circ} \mathrm{C}$ was too intense to allow the development of an apoptotic response, resulting in a larger concentration of necrotic zooxanthellar cells. By comparison, Strychar et al. [44] observed increased apoptotic zooxanthellae from 0 to $\sim 30 \%$ in the Indo-Pacific coral Acropora hyacinthus when temperatures at $28^{\circ} \mathrm{C}$ and at $32^{\circ} \mathrm{C}$ were compared. They showed that zooxanthellate corals that were less susceptible to heat stress expelled higher concentrations of apoptotic zooxanthellae ranging from $0-10 \%$ under intense heat stress $\left(34^{\circ} \mathrm{C}\right)$, with necrosis being more prominent $(\leq 20 \%)$. Strychar and Sammarco $[73,74]$ and Sammarco and Strychar [10] have also shown that some host corals in the IndoPacific, specifically Acropora hyacinthus, Porites solida, and Favites complanata have a much broader temperature tolerance (i.e., $34-36^{\circ} \mathrm{C}$ ) than their endosymbiotic zooxanthellae $\left(30-32^{\circ} \mathrm{C}\right.$ ), exhibiting adaptation (or exaptation) towards increased SWTs. Fitt et al. [75] observed similar results in the Indo-Pacific corals Porites cylindrica and Stylophora pistillata, and reviews by Baird et al. [76], who comparatively assessed the role of coral hosts versus zooxanthellae in a wide variety of corals worldwide, support the concepts of Strychar and Sammarco $[73,74]$ and Sammarco and Strychar $[10]$ — such that exaptation to heat stress by coral hosts may result from numerous prior exposures to varying climates.

The growth of Symbiodinium by mitosis in situ under bleaching conditions provides information regarding whether a host coral will survive, maintain its standing stock of zooxanthellae, or become reinfected by an alternate zooxanthellar clade. The standing stock density of zooxanthellae is regulated by symbiont reproduction in hospite as well as by the degradation and removal of zooxanthellae through the gastrodermal cavity and tentacles of the host [77-79]. Here, the expulsion of mitotic zooxanthellae was relatively constant in experimental corals from the FGBNMS and FKNMS. Strychar et al. [45], however, noted that expelled zooxanthellae exhibited higher growth rates at $34^{\circ} \mathrm{C}$ versus lower experimental temperatures. The low abundance of mitotic zooxanthellae we observed in $M$. cavernosa may indicate a preference toward host autotrophy (i.e., ingesting the zooxanthellae) versus increased host heterotrophy via polyps increasing their feeding rate. Increased heterotrophy is known to occur in some cnidarians when under stress (84, 85 , Goreau, pers. com.). 
Interestingly, we note that the homeostatic control of zooxanthellae, although not monitored extensively (zooxanthellae were not continuously collected) in this study, was observed. It should, therefore, be concluded that simple alterations to the methods used for such studies including the continual collection of zooxanthellae over a given period of time be employed in order to understand the control of endosymbiont concentration within a host coral. Information regarding the homeostatic control of endosymbionts with respect to sensitive and hearty coral species may provide further insight into the importance of host endosymbiont interactions as well as a means to determine the role of specific proteins on host control of zooxanthellae density.

\section{Conclusion: Adaptation in Montastraea cavernosa to Heat Stress}

Plant/animal symbioses require cooperative communication between the host and symbiont (i.e., cell signaling) in order to remain effective [80]. It is important to again note that the diversity and concentration of zooxanthellae within colonies of $M$. cavernosa has been shown to be consistently clade C and between $2.3-4.2 \times 10^{6} \mathrm{cells} \mathrm{cm}^{-2}$ [62-68]. Further this study utilized only the red color morph of M. cavernosa, and, therefore, the pigments associated with the host were similar for all fragments. Isolating the degree and duration of heat stress, we hypothesize that during heat stress, the sensitive connection that evolved over many millennia between the coral zooxanthellar symbioses is potentially caused by the disruption of the Calvin Cycle $[42,81]$. Due to the large percentage of carbon supplied to the host by algal photosynthesis in hospite, the symbiosis has evolved mechanisms to reduce the impacts of harmful byproducts (e.g., radical oxygen species-ROS), most likely through fluorescent proteins [26]. In organisms not repeatedly exposed to such stressors, mechanisms to cope with increased stimulation of apoptosis and any associated byproducts may not be well developed and subsequently may cause particular species to show increased symptoms of bleaching. Those species that show increased sensitivity to bleaching, for example, FGBNMS coral as opposed to FKNMS coral, may require increased frequency of exposure to mild heat stress (i.e., acclimation) and/or an increased period of time over which seawater temperature increase (i.e., adaptation) to become less sensitive.

To our knowledge, this is the first study that has experimentally examined the effects of heat stress on Montastraea cavernosa in the Caribbean (i.e., FKNMS) versus the Gulf of Mexico (i.e., FGBNMS). Further, we believe these sites to be a unique opportunity to determine the response of coral to bleaching particularly with respect to the degree that host adaptation/exaptation as well as symbiont shuffling may interact to resist thermal stress. In situ bleaching observations by Precht et al. [30] indicate that $4-10 \%$ of all corals are suffering effects of increased thermal stress at the FGBNMS. Our data indicate a potential source for the variation in this susceptibility to heat stress and bleaching, which we propose as regional adaptation most likely based on range and variation of temperatures not normally experienced.

\section{Acknowledgments}

The authors thank the Texas Parks and Wildlife for seawater transportation services, Texas Flower Garden Banks National Marine Sanctuary (Permit No. FGBNMS-2007-010) and the Florida Keys National Marine Sanctuary (Permit No. FKNMS 0648-0141) for permits given K. B. Strychar. They also thank Texas Research Development Fund for grants to K. B. Strychar. Special thanks to G. P. Schmahl and E Hickerson at NOAA (FGBNMS) for ship time and J. Delaney and E. Bartels at Mote Marine Lab for collecting coral.

\section{References}

[1] W. Kiessling, "Geologic and biologic controls on the evolution of reefs," Annual Review of Ecology, Evolution, and Systematics, vol. 40, pp. 173-192, 2009.

[2] A. C. Allwood, M. R. Walter, B. S. Kamber, C. P. Marshall, and I. W. Burch, "Stromatolite reef from the early Archaean era of Australia," Nature, vol. 441, no. 7094, pp. 714-718, 2006.

[3] C. Perrin, "Tertiary: the emergence of modern reef ecosystems," vol. 72, pp. 587-621, 2002.

[4] Great Barrier Reef, "United Nations Environment ProgramGreat Barrier Reef, Queensland Australia,” pp. 9, 2010, http:// sea.unep-wcmc.org/sites/wh/pdf/GreatBarrierReef.

[5] D. Bryant, L. Burke, J. McManus, and M. Spalding, Reefs at Risk: A Map-Based Indicator of Threats to the World's Coral Reefs, World Resources Institute, Washington, DC, USA, 1998.

[6] O. Hoegh-Guldberg, "Climate change, coral bleaching and the future of the world's coral reefs," Marine and Freshwater Research, vol. 50, no. 8, pp. 839-866, 1999.

[7] N. Knowlton, "The future of coral reefs," Proceedings of the National Academy of Sciences of the United States of America, vol. 98, no. 10, pp. 5419-5425, 2001.

[8] T. P. Hughes, A. H. Baird, D. R. Bellwood et al., "Climate change, human impacts, and the resilience of coral reefs," Science, vol. 301, no. 5635, pp. 929-933, 2003.

[9] T. R. McClanahan, M. Ateweberhan, C. A. Muhando, J. Maina, and M. S. Mohammed, "Effects of climate and seawater temperature variation on coral bleaching and mortality," Ecological Monographs, vol. 77, no. 4, pp. 503-525, 2007.

[10] P. W. Sammarco and K. B. Strychar, "Effects of climate change and global warming on coral reefs: exaptation in corals and the evolution of their zooxanthellae," Environmental Bioindicators, vol. 4, pp. 9-45, 2009.

[11] C. Wilkinson and G. Hodgson, "Coral reefs and the 1997-1998 mass bleaching and mortality," Nature and Resources, vol. 35, no. 2, pp. 16-25, 1999.

[12] T. Spencer, K. A. Teleki, C. Bradshaw, and M. D. Spalding, "Coral bleaching in the southern Seychelles during the 19971998 Indian Ocean warm event," Marine Pollution Bulletin, vol. 40, no. 7, pp. 569-586, 2000.

[13] R. Berkelmans, G. De'ath, S. Kininmonth, and W. J. Skirving, "A comparison of the 1998 and 2002 coral bleaching events on the Great Barrier Reef: spatial correlation, patterns, and predictions," Coral Reefs, vol. 23, no. 1, pp. 74-83, 2004.

[14] Australian Government, "Climate change-potential impacts and costs, Great Barrier Reef," pp. 3, 2008, http://www.climatechange.gov.au/climate-change/impacts/national-impacts/ / media/publications/adaptation/fs-QLD-pdf.pdf.

[15] C. D. Harvell, K. Kim, J. M. Burkholder et al., "Emerging marine diseases-climate links and anthropogenic factors," Science, vol. 285, no. 5433, pp. 1505-1510, 1999. 
[16] C. D. Harvell, C. E. Mitchell, J. R. Ward et al., "Climate warming and disease risks for terrestrial and marine biota," Science, vol. 296, no. 5576, pp. 2158-2162, 2002.

[17] J. Goldberg and C. Wilkinson, "Global threats to coral reefs: coral bleaching, global climate change, disease, predator plagues, and invasive species in status of coral reefs of the world 2004," Australian Institute of Marine Science, pp. 67-92, 2004.

[18] K. D. Lafferty, J. W. Porter, and S. E. Ford, "Are diseases increasing in the ocean?" Annual Review of Ecology, Evolution, and Systematics, vol. 35, pp. 31-54, 2004.

[19] E. Weil, I. Urreiztieta, and J. Garzón-Ferreira, "Geographic variability in the incidence of coral and octocoral diseases in the wider Caribbean," in Proceedings of the 9th International Coral Reef Symposium, vol. 2, pp. 1,231-1,237, Bali, Indonesia, 2002.

[20] E. Weil, G. Smith, and D. L. Gil-Agudelo, "Status and progress in coral reef disease research," Diseases of Aquatic Organisms, vol. 69, no. 1, pp. 1-7, 2006.

[21] J. W. Porter and O. W. Meier, "Quantification of loss and change in Floridian reef coral populations," American Zoologist, vol. 32, no. 6, pp. 625-640, 1992.

[22] D. G. Bourne, M. Garren, T. M. Work, E. Rosenberg, G. W. Smith, and C. D. Harvell, "Microbial disease and the coral holobiont," Trends in Microbiology, vol. 17, no. 12, pp. 554$562,2009$.

[23] R. B. Aronson, W. F. Prechit, and I. G. Macintyre, "Extrinsic control of species replacement on a Holocene reef in Belize: the role of coral disease," Coral Reefs, vol. 17, no. 3, pp. 223 230, 1998.

[24] K. P. Sutherland, J. W. Porter, and C. Torres, "Disease and immunity in Caribbean and Indo-Pacific zooxanthellate corals," Marine Ecology Progress Series, vol. 266, pp. 273-302, 2004.

[25] E. Weil, "Coral reef diseases in the wider Caribbean," in Coral Health and Diseases, E. Rosenberg and Y. Loya, Eds., pp. 35-68, Springer, New York, NY, USA, 2004.

[26] V. M. Weis, "Cellular mechanisms of Cnidarian bleaching: stress causes the collapse of symbiosis," Journal of Experimental Biology, vol. 211, no. 19, pp. 3059-3066, 2008.

[27] Florida DEP (Department of Environmental Protection), "Florida's coral reefs, online," 2009, http://www.dep.state.fl.us/ coastal/habitats/coral/.

[28] C. Reich and D. Hickey, "Coral coring in the flower garden banks national marine sanctuary - a collaborative effort," U.S. Geological Survey Sound Waves, vol. 74, pp. 1-13, 2005.

[29] B. Causey, J. Delaney, E. Diaz et al., "Status of coral reefs in the U.S. Caribbean and Gulf of Mexico: Florida, Texas, Puerto Rico, US Virgin Islands, Navassa in Status of Coral Reefs of the World 2002," Australian Institute of Marine Science, pp. 251276, 2002.

[30] W. F. Precht, R. B. Aronson, K. J. P. Deslarzes et al., "Longterm monitoring at the East and West Flower Garden Banks, 2004-2005; final report," 2006, US Dept. of the Interior, Minerals Management Service, Gulf of Mexico OCS Region, New Orleans LA. OCS study, pp. 182.

[31] G. P. Schmahl, E. L. Hickerson, and W. F. Precht, "Biology and ecology of coral reefs and coral communities in the flower garden banks region, Northwestern Gulf of Mexico," Coral Reefs of the World: Coral Reefs of the USA, pp. 221-261, 2008.

[32] P. L. Jokiel and S. L. Coles, "Effects of heated effluent on hermatypic corals at Kahe point, Oahu," Pacific Science, vol. 28, pp. 1-18, 1974.
[33] P. W. Glynn, "Widespread coral mortality and the 1982-83 El Niño warming event," Environmental Conservation, vol. 11, no. 2, pp. 133-146, 1984.

[34] P. W. Glynn and L. D'Croz, "Experimental evidence for high temperature stress as the cause of El Niño-coincident coral mortality," Coral Reefs, vol. 8, no. 4, pp. 181-191, 1990.

[35] T. J. Goreau and R. L. Hayes, "Coral bleaching and ocean 'Hot Spots,” Ambio, vol. 23, no. 3, pp. 176-180, 1994.

[36] T. J. Goreau and R. L. Hayes, "Global coral reef bleaching and sea surface temperature, trends from satellite-derived hotspot analysis," World Resource Review, vol. 17, pp. 254-292, 2005.

[37] J. M. West and R. V. Salm, "Resistance and resilience to coral bleaching: implications for coral reef conservation and management," Conservation Biology, vol. 17, no. 4, pp. 956-967, 2003.

[38] R. J. Jones, O. Hoegh-Guldberg, A. W. D. Larkum, and U. Schreiber, "Temperature-induced bleaching of corals begins with impairment of the $\mathrm{CO}_{2}$ fixation mechanism in zooxanthellae," Plant, Cell and Environment, vol. 21, no. 12, pp. 12191230, 1998.

[39] A. H. Baird and P. A. Marshall, "Mortality, growth and reproduction in scleractinian corals following bleaching on the Great Barrier Reef," Marine Ecology Progress Series, vol. 237, pp. 133-141, 2006.

[40] H. A. Oxenford, R. Roach, A. Brathwaite et al., "Quantitative observations of a major coral bleaching event in Barbados, Southeastern Caribbean," Climatic Change, vol. 87, no. 3-4, pp. 435-449, 2007.

[41] R. W. Buddemeier and D. G. Fautin, "Coral bleaching as an adaptive mechanism," BioScience, vol. 43, pp. 320-326, 1993.

[42] R. A. Kinzie III, M. Takayama, S. R. Santos, and M. A. Coffroth, "The adaptive bleaching hypothesis: experimental tests of critical assumptions," Biological Bulletin, vol. 200, no. 1, pp. 51-58, 2001.

[43] D. G. Fautin and R. W. Buddemeier, "Adaptive bleaching: a general phenomenon," Hydrobiologia, vol. 530-531, pp. 459467, 2004.

[44] K. B. Strychar, M. Coates, P. W. Sammarco, and T. J. Piva, "Bleaching as a pathogenic response in scleractinian corals, evidenced by high concentrations of apoptotic and necrotic zooxanthellae," Journal of Experimental Marine Biology and Ecology, vol. 304, no. 1, pp. 99-121, 2004.

[45] K. B. Strychar, M. Coates, and P. W. Sammarco, "Loss of Symbiodinium from bleached Australian scleractinian corals (Acropora hyacinthus, Favites complanata and Porites solida)," Marine and Freshwater Research, vol. 55, no. 2, pp. 135-144, 2004.

[46] K. B. Strychar, M. Coates, and T. J. Piva, "Effect of water temperature on the viability of Symbiodinium lost from the scleractinian coral Acropora hyacinthus," Proceedings of the Australiean Society of Biochemistry and Molecular Biology, vol. 1, pp. 61-64, 2001.

[47] K. B. Strychar, M. Coates, P. W. Sammarco, T. J. Piva, and P. T. Scott, "Loss of Symbiodinium from bleached soft corals Sarcophyton ehrenbergi, Sinularia sp. and Xenia sp," Journal of Experimental Marine Biology and Ecology, vol. 320, no. 2, pp. 159-177, 2005.

[48] A. H. Wyllie, R. G. Morris, A. L. Smith, and D. Dunlop, "Chromatin cleavage in apoptosis: association with condensed chromatin morphology and dependence on macromolecular synthesis," Journal of Pathology, vol. 142, no. 1, pp. 67-77, 1984.

[49] V. A. Fadok, D. R. Voelker, P. A. Campbell, J. J. Cohen, D. L. Bratton, and P. M. Henson, "Exposure of phosphatidylserine on the surface of apoptotic lymphocytes triggers specific 
recognition and removal by macrophages," Journal of Immunology, vol. 148, no. 7, pp. 2207-2216, 1992.

[50] I. Herr and K. M. Debatin, "Cellular stress response and apoptosis in cancer therapy," Blood, vol. 98, no. 9, pp. 2603 $2614,2001$.

[51] M. S. Jurkowitz-Alexander, R. A. Altschuld, C. M. Hohl et al., "Cell swelling, blebbing, and death are dependent on ATP depletion and independent of calcium during chemical hypoxia in a glial cell line (ROC-1)," Journal of Neurochemistry, vol. 59, no. 1, pp. 344-352, 1992.

[52] K. B. Strychar, P. W. Sammarco, and T. J. Piva, "Apoptotic and necrotic stages of Symbiodinium (Dinophyceae) cell death activity: bleaching of soft and scleractinian corals," Phycologia, vol. 43, no. 6, pp. 768-777, 2004.

[53] S. R. Dunn, C. E. Schnitzler, and V. M. Weis, "Apoptosis and autophagy as mechanisms of dinoflagellate symbiont release during cnidarian bleaching: every which way you lose," Proceedings of the Royal Society B, vol. 274, no. 1629, pp. 30793085, 2007.

[54] C. A. Downs, E. Kramarsky-Winter, J. Martinez et al., "Symbiophagy as a cellular mechanism for coral bleaching," Autophagy, vol. 5, no. 2, pp. 211-216, 2009.

[55] A. M. Cuervo, "Autophagy: many paths to the same end," Molecular and Cellular Biochemistry, vol. 263, no. 1, pp. 5572, 2004.

[56] D. Gozuacik and A. Kimchi, "Autophagy as a cell death and tumor suppressor mechanism," Oncogene, vol. 23, no. 16, pp. 2891-2906, 2004

[57] D. K. Hagman and S. R. Gittings, "Coral bleaching on high latitude reefs at the flower garden banks, NW Gulf of Mexico," in Proceedings of the 7th International Coral Reef Symposium, vol. 1, pp. 38-43, 1992.

[58] P. A. Marshall and A. H. Baird, "Bleaching of corals on the Great Barrier Reef: differential susceptibilities among taxa," Coral Reefs, vol. 19, no. 2, pp. 155-163, 2000.

[59] Y. Loya, K. Sakai, K. Yamazato, Y. Nakano, H. Sambali, and R. van Woesik, "Coral bleaching: the winners and the losers," Ecology Letters, vol. 4, no. 2, pp. 122-131, 2001.

[60] T. J. Bright, "Hermatypes of the flower garden banks, northwestern G of M: a comparison to other western Atlantic reefs," Bulletin of Marine Science, vol. 34, pp. 461-476, 1984.

[61] U. E. Siebeck, N. J. Marshall, A. Klüter, and O. Hoegh-Guldberg, "Monitoring coral bleaching using a colour reference card," Coral Reefs, vol. 25, no. 3, pp. 453-460, 2006.

[62] M. P. Lesser, M. Slattery, M. Stat, M. Ojimi, R. D. Gates, and A. Grottoli, "Photoacclimatization by the coral Montastraea cavernosa in the mesophotic zone: light, food, and genetics," Ecology, vol. 91, no. 4, pp. 990-1003, 2010.

[63] Z. Billlinghurst, A. E. Douglas, and H. G. Trapido-Rosenthal, "On the genetic diversity of the symbiosis between the coral Montatstraea cavernosa and zooxanthellae in Bermuda," in Proceedings of the 8th International Coral Reef Symposium, vol. 2, pp. 1291-1294, 1997.

[64] A. M. Savage, M. S. Goodson, S. Visram, H. Trapido-Rosenthal, J. Wiedenmann, and A. E. Douglas, "Molecular diversity of symbiotic algae at the latitudinal margins of their distribution: dinoflagellates of the genus Symbiodinium in corals and sea anemones," Marine Ecology Progress Series, vol. 244, pp. 17-26, 2002.

[65] A. A. Venn, F. K. Weber, J. E. Loram, and R. J. Jones, "Deep zooxanthellate corals at the high latitude Bermuda Seamount," Coral Reefs, vol. 28, no. 1, p. 135, 2009.

[66] A. C. Baker and R. Rowan, "Diversity of symbiotic dinoflagellates (zooxanthellae) in scleractinian corals of the Caribbean and Eastern Pacific," in Proceedings of the 8th International Coral Reef Symposium, vol. 2, pp. 1301-1306, 1997.

[67] T. C. LaJeunesse, "Diversity and community structure of symbiotic dinoflagellates from Caribbean coral reefs," Marine Biology, vol. 141, no. 2, pp. 387-400, 2002.

[68] T. L. Goulet, "Most corals may not change their symbionts," Marine Ecology Progress Series, vol. 321, pp. 1-7, 2006.

[69] Council of Science Editors SMC, Ed., Scientific Style and Format: The CSE Manual for Authors, Editors, and Publishers, The Council, Reston, Va, USA, 7th edition, 2006.

[70] R. Middlebrook, O. Hoegh-Guldberg, and W. Leggat, "The effect of thermal history on the susceptibility of reef-building corals to thermal stress," Journal of Experimental Biology, vol. 211, no. 7, pp. 1050-1056, 2008.

[71] R. Iglesias-Prieto, V. H. Beltrán, T. C. LaJeunesse, H. ReyesBonilla, and P. E. Thomé, "Different algal symbionts explain the vertical distribution of dominant reef corals in the eastern Pacific," Proceedings of the Royal Society of London Biology, vol. 271, no. 1549, pp. 1757-1763, 2004.

[72] T. A. Oliver and S. R. Palumbi, "Many corals host thermally resistant symbionts in high-temperature habitat," Coral Reefs, vol. 30, pp. 241-250, 2011.

[73] K. B. Strychar and P. W. Sammarco, "Exaptation in corals to high seawater temperatures: low concentrations of apoptotic and necrotic cells in host coral tissue under bleaching conditions," Journal of Experimental Marine Biology and Ecology, vol. 369, no. 1, pp. 31-42, 2009.

[74] K. B. Strychar and P. W. Sammarco, "Exaptation in the host coral Favites complanata (Ehrenbert, 1834; Scleractinia, Faviidae) to increased sea-surface temperatures," in Proceedings of the 11th International Coral Reef Symposium, pp. 1329-1333, Fort Lauderdale, Fla, USA, 2008.

[75] W. K. Fitt, R. D. Gates, O. Hoegh-Guldberg et al., "Response of two species of Indo-Pacific corals, Porites cylindrica and Stylophora pistillata, to short-term thermal stress: the host does matter in determining the tolerance of corals to bleaching," Journal of Experimental Marine Biology and Ecology, vol. 373, no. 2, pp. 102-110, 2009.

[76] A. H. Baird, R. Bhagooli, P. J. Ralph, and S. Takahashi, "Coral bleaching: the role of the host," Trends in Ecology and Evolution, vol. 24, no. 1, pp. 16-20, 2009.

[77] E. A. Titlyanov, T. V. Titlyanova, V. A. Leletkin, J. Tsukahara, R. van Woesik, and K. Yamazato, "Degradation of zooxanthellae and regulation of their density in hermatypic corals," Marine Ecology Progress Series, vol. 139, no. 1-3, pp. 167-178, 1996.

[78] R. J. Jones and D. Yellowlees, "Regulation and control of intracellular algae ( = zooxanthellae) in hard corals," Philosophical Transactions of the Royal Society B, vol. 352, no. 1352, pp. 457468, 1997.

[79] E. A. Titlyanov, J. Tsukahara, T. V. Titlyanova, V. A. Leletkin, and R. van Woesik, "Zooxanthellae population density and physiological state of the coral Stylophora pistillata during starvation and osmotic shock," Symbiosis, vol. 28, no. 4, pp. 303-322, 2000.

[80] J. Vidal-Dupiol, M. Adjeroud, E. Roger et al., "Coral bleaching under thermal stress: putative involvement of host/symbiont recognition mechanisms," BioMed Central Physiology, vol. 9, no. 1, pp. 1-16, 2009.

[81] A. Rokka, A. Eva-Mari, G. H. Reinhold, A. Bertil, and A. V. Vener, "Dephosphorylation of photosystem II reaction center proteins in plant photosynthetic membranes as an immediate response to abrupt elevation of temperature," Plant Physiology, vol. 123 , no. 4, pp. 1525-1536, 2000. 

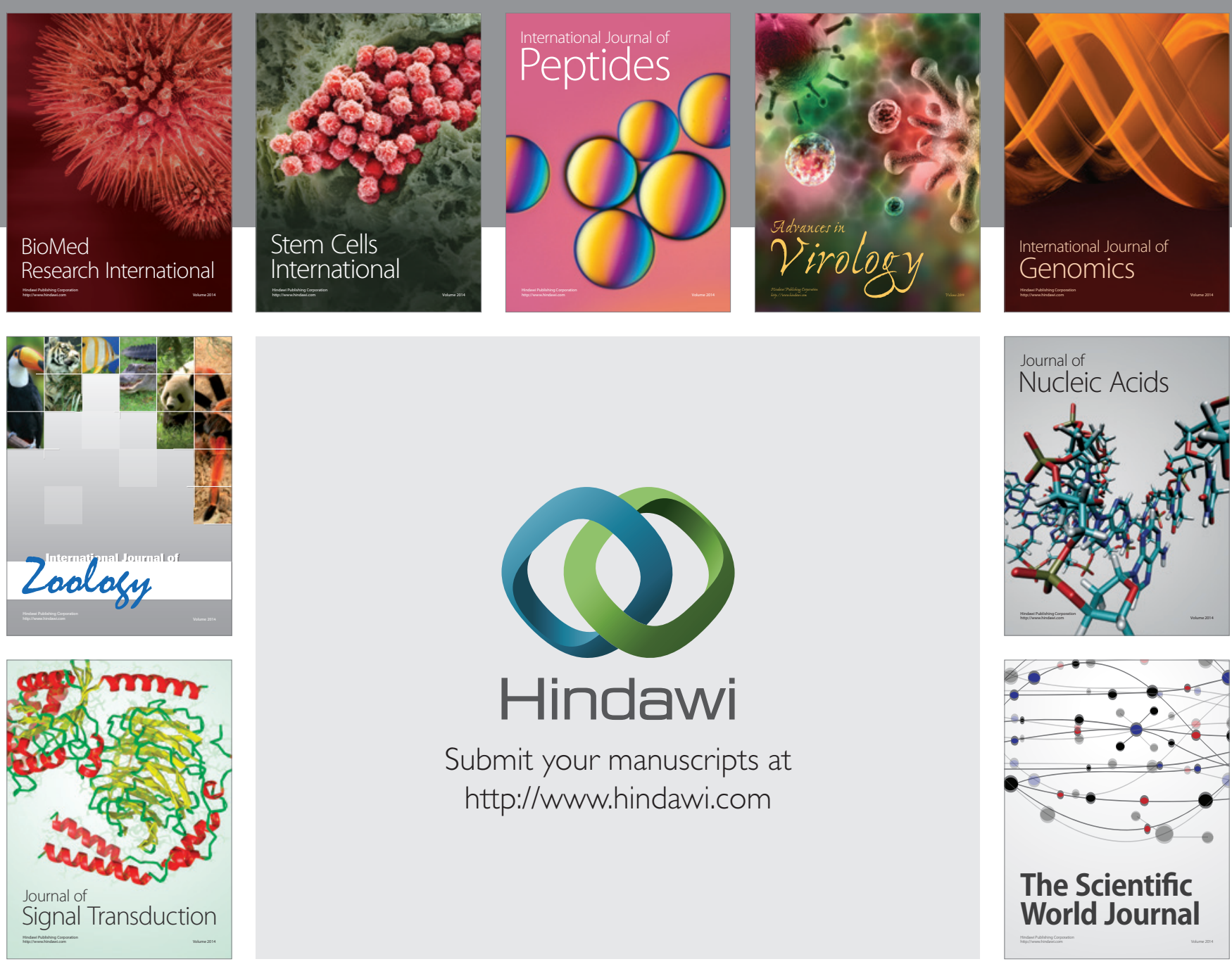

Submit your manuscripts at

http://www.hindawi.com
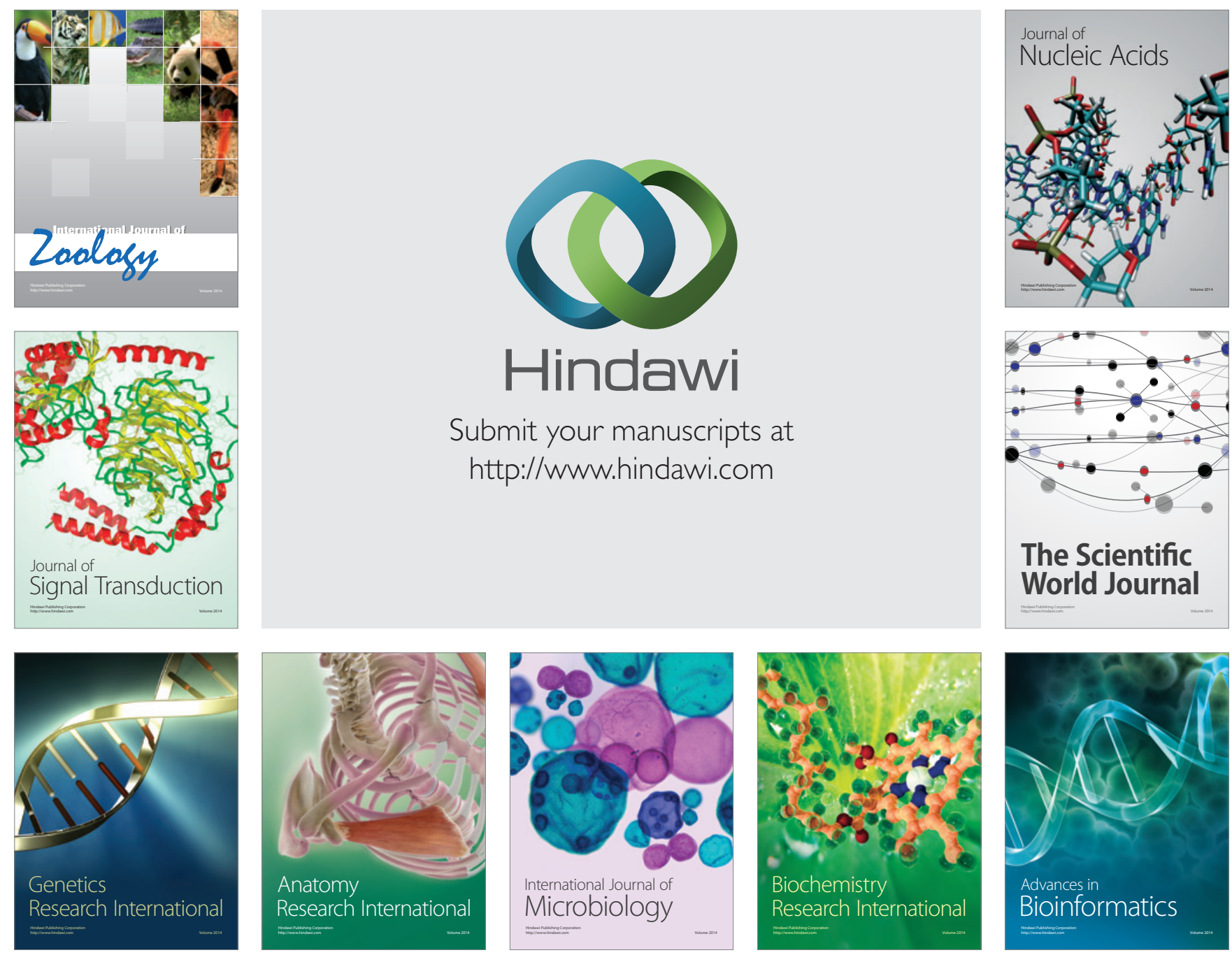

The Scientific World Journal
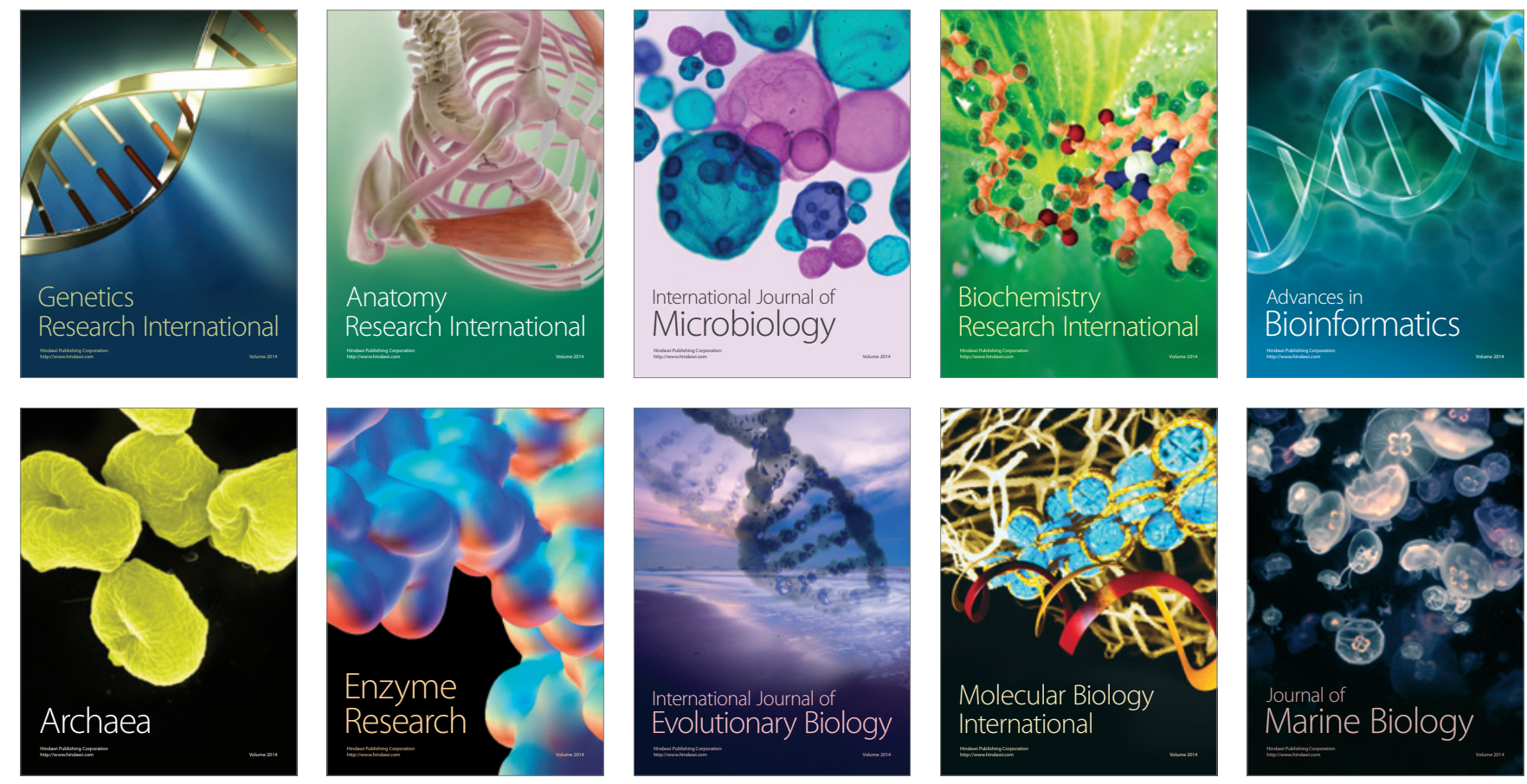